\title{
El monje que vendió su Ferrari.
}

\author{
Sharma, Robin S. \\ 1997 \\ Ed. Debolsillo \\ Canadá \\ Magdalena Hernández Hernández \\ magdabeatle@hotmail.com
}

Este libro relata la historia de un afamado abogado llamado Julián Mantle, que en su afán de tener más prestigio y alcanzar un nivel económico alto, se olvidó de vivir; de darle el justo valor a su familia y amigos pues los fue perdiendo poco a poco sin darse cuenta.

Al final de esta historia comprendió que lo importante de vivir era formar parte de vida los suyos, porque no tenía sentido ser el exitoso abogado si no contaba con quien compartir sus logros.

Tomo comienza cuando Julián sufre un infarto por la vida tan agitada que llevaba. Este suceso cambió el rumbo de su vida. Decide vender todas sus propiedades, incluido el Ferrari rojo que tanto amaba, emprende un viaje hacia la India, dejando a cargo del buffet a su amigo John. Tres años pasaron sin noticias de Julián, hasta que un día a las afueras del buffet se encontraba un hombre lleno de juventud y vitalidad. John salió y no podía creerlo, era Julián, comenzó a contarle su aventura por la India. Mencionó que vivió con unos monjes, en un lugar llamado Sivana, cerca del Himalaya; ahí le enseñaron, por medio de una fábula toda la sabiduría que él requería.

Esta fabula contiene 7 elementos fundamentales: jardín: dominar la mente y cultivarla cada día, faro rojo: en la vida debemos tener un propósito claro y alcanzarlo, luchador de sumo:

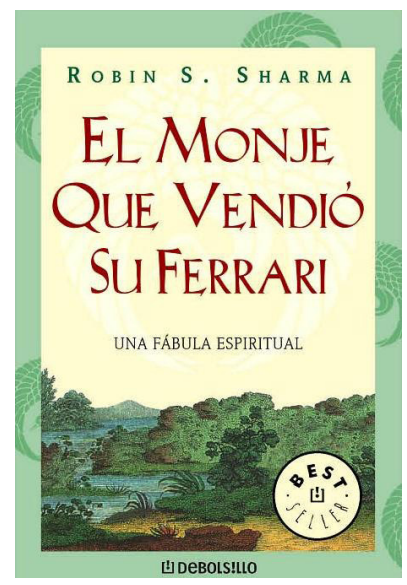

tener autodominio, el éxito empieza desde dentro, cable rosa: disciplina, se logra realizando pequeños actos de coraje, cronógrafo de oro: respetar tu tiempo, es tan valioso que nunca regresará, rosas amarillas: bondad, contribuir con los demás desinteresadamente, camino de diamantes: vivir el hoy, ni el pasado ni el futuro, pues nunca habrá un día igual al de ahora.

Después que John escucho todo esto, entró en razón, la vida simplemente hay que vivirla y disfrutarla. Habiendo terminado de contar su vivencia en el Himalaya, Julián se marchó satisfecho, convencido que su experiencia servirá de ejemplo para aquellos que se encuentren en circunstancias similares.

Este libro lo sugiero para reflexionar la forma en que estamos viviendo actualmente, nos preocupamos más en dar una buena imagen a los demás, por lograr el éxito laboral; y vamos dejando a un lado la familia y los amigos. Como dice en las últimas paginas del libro: "Debemos dejar de posponer nuestra felicidad a costa de la realización". Seria buena idea que pongamos en práctica algunas de las enseñanzas que nos muestra el libro, pues son situaciones que todos conocemos, pero no nos ponemos a pensar lo felices que seríamos si las tomáramos en cuenta. 